Folia primat. 1971;14:I-IV

\title{
Contents, Vol. 14, 1971
}

Editor:

J. Biegert, Zurich

Editorial Board:

E. L. Bone, Louvain

W. Fiedler, Wien

H. F. Harlow, Madison, Wise.

H. Hediger, Zurich

W. C. Osman Hill, Folkestone

H. Hofer, Covington, La.

J. Hürzeler, Basel

J. R. Napier, London

J. Piveteau, Paris

A. Remane, Kiel

A. H. Schultz, Zurich

D. Starck, Frankfurt am Main

W. L. Straus, Jr., Baltimore, Md.

S. L. Washburn, San Francisco, Calif.

H. Zapfe, Wien

S. Zuckerman, Birmingham

$\mathrm{S} 7 / 8 \S$ lí S. Karger-Basel-München·Paris- London-New York- Sydney

S. Karger · Basel · München · Paris · London · New York · Sydney Arnold-Böcklin-Strasse 25, CH-4000 Basel 11 (Switzerland)

All rights, including that of translation into other languages, reserved. Photomechanic reproduction (photocopy, microcopy) of this volume or parts thereof without special permission of the publishers is prohibited.

(C) Copyright 1971 by S. Karger AG, Verlag für Medizin und Naturwissenschaften, Basel Printed in Switzerland by Schellenberg-Druck, Pfäffikon ZH

Contents

Andersson, Annette: vide Doyle, G. A.

Angus, Shannon: Water-Contact Behavior of Chimpanzees 51

Arnold, R. C.: vide Rumbaugh, D. M.

Arnold, R. C. and Rumbaugh, D. M.: Extinction: A Comparative Primate Study

oi Lemur and Cercopithecus 161

Baldwin, J. D.: The Social Organization of a Semifree-Ranging Troop of Squirrel

Monkeys (Saimiri sciureus) 23 
Bearder, S. K.: vide Doyle, G. A.

Brett, Irene J.: vide Haines, D. E.

Bronsdon, Melinda A.: vide Dillingham, L. A.

Castell, R. and Heinrich, Barbara: Rank Order in a Captive Female Squirrel

Monkey Colony 182

Chalmers, N. R. and Rowell, T. E.: Behaviour and Female Reproductive Cycles in

a Captive Group of Mangabeys

Cornell, R.: vide Kling, A.

Dillingham, L. A.; Morrow, Anne C, and Bronsdon, Melinda A.: A Comparison

of the Hemograms of M $\alpha \operatorname{coc} \alpha$ mulatt $\alpha, M \alpha c \alpha c \alpha$ nemestrin $\alpha$ and Papio

anubis 241

Doyle, G. A.; Andersson, Annette, and Bearder, S. K.: Reproduction in the

Lesser Bushbaby (Galago senegalensis moholí) under Semi-Natural Con

ditions 15

Groves, C. P.: Geographic and Individual Variation in Bornean Gibbons, with

Remarks on the Systematics of the Subgenus Hylobates 139

Haines, D. E.; Holmes, K. R., and Brett, Irene J.: The Hemogram of the Colonized

Lesser Bushbaby (Golago senegalensis) 95

Heinrich, Barbara: vide Castell, R.

Hill, W. C. O. and Sabater Pi, J.: Anomaly of the Hallux in a Lowland Gorilla

(Gorilla gorilla gorilla Savage and Wyman) 252

Holmes, K. R.: vide Haines, D. E.

Kanagasuntheram, R.: vide Leela, K.

Kling, A. and Cornell, R.: Amygdalectomy and Social Behavior in the Caged

Stump-tailed Macaque (Macaca speciosa) 190

Lamey, D.: vide Michejda, Maria

Leela, K. and Kanagasuntheram, R.: Craniopharyngeal Canal and Pharyngeal

Hypophysis in the Siamang Gibbon (Symphalangus syndactylus) ... 118 Lerner, R. P.: vide

Smith, I. Luscombe, G.: vide Reynolds, V. Michejda, Maria and Lamey, D.: Flexion and Metric

Age Changes of the Cranial

Base in the Macaca mulatta. I. Infant and Juveniles 84

Contents

Morrow, Anne C.: vide Dillingham, L. A.

Preuschoft, H.: Body Posture and Mode of Locomotion in Early Pleistocene

Hominids 209

Reynolds, V. and Luscombe, G.: On the Existence of Currently Described Sub

species in the Chimpanzee (Pan troglodytes) 129

Roberts, J. A. and Seibold, H. R.: The Histology of the Primate Urethra

Roberts, Pamela: Social Interactions of Galago crassicaudatus 171

Rowell, T. E.: vide Chalmers, N. R.

Rumbaugh, D. M.: vide Arnold, R. C.

Rumbaugh, D. M. and Arnold, R. C.: Learning: A Comparative Study of Lemur and

Cercopithecus 154

Sabater Pi, J.: vide Hill, W. C. O.

Schmidt, R. E.: Colobomas in Non-human Primates 256

Seibold, H. R.: vide Roberts, J. A. 
Smith, I.: Comparative Biochemistry of the Primates. I. Amino Acid Patterns in the Blood and Urine 101

Smith, I. and Lerner, R. P.: Comparative Biochemistry of the Primates. II. The Indole Compounds of Primate Blood and Urine 110

Stynson, J. M.: Intrarenal Arterial Patterns in Nonhuman Primates 70

Wolf, R. H.: Placenta Previa in a Patas Monkey (Erythrocebus patas)

Book Reviews - Buchbesprechungen - Livres nouveaux 123

Announcement - Mitteilung-Communication 268 